\section{Grunnbok i sosialmedisinsk praksis, teori og ideologi}

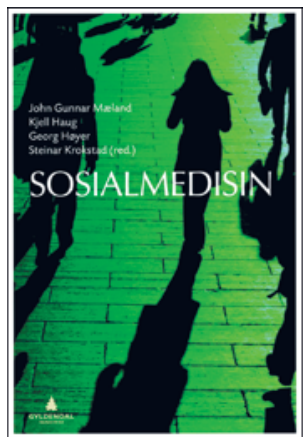

John Gunnar Mæland, Kjell Haug, Georg Høyer et al.

Sosialmedisin

2. utg. 293 s, tab, ill. Oslo: Gyldendal

Akademisk, 2011. Pris NOK 585

ISBN 978-82-05-39915-0

Førsteutgåva i 2004 representerte ei fornying av læreboktilbodet i faget (1). Den nye utgåva er meir enn ein oppdatert versjon. To av fire redaktørar er bytta ut, fleire nye forfattarar er komne til. Stoffet er omredigert og komprimert; sidetalet er redusert frå 442 til 293. Redaktørane har lykkast med å unngå unødige gjentakingar. Bergensprofilen er styrkt, halvparten av 14 forfattarar har si fagtilknyting der.

Boka er logisk bygd opp med seksten kapittel, fordelte på tre hovuddelar: Sosialmedisinens grunnlag, Det norske velferdsapparatet (huff, for eit ord!) og Sosialmedisin i praksis. Kvart kapittel har innleiingsvis ein kortfatta ingress. I tekstboksar på farga bakgrunn gir forfattarane detaljert informasjon om avgrensa tema. Tabellar, diagram og figurar er informative. I tillegg til litteraturreferansar blir kvart kapittel avslutta med anbefaling av to til tre titlar for vidare lesing.

I innleiingskapitlet skisserer forfattarane tre sosialmedisinske kjerneområde: innverknad av sosiale tilhøve på risiko for helsesvikt; sosiale konsekvensar av svekka helse, både for samfunnet og for enkeltmennesket, og fordeling og funksjon av velferdsordningane.

I tillegg til å formidle faktakunnskap har boka ei gjennomgåande verdimessig forankring i den nordiske velferdsstaten med offentlege, solidariske og universelle ordningar. Forfattarane åtvarar mot auka sosioøkonomiske skilnader og fragmentering av velferdssystemet. Omsynet til svakstilte grupper er ein raud tråd. Etter mitt syn er den klare ideologiske profilen ein styrke, i pakt med Einar Førde si erkjenning av at når det kjem til stykket, så er vi alle sosialdemokratar.

Kapittel 6 om dei norske helse- og omsorgstenestene - der assisterande helsedirektør er medforfattar - er oversiktleg og føregrip delvis samhandlingsreforma og ny helselovgiving frå 2012. Men eit par stader er framstillinga diskutabel eller direkte feil. På side 100 finn ein omgrepet «kommunelege I». Det bør anten heite «kommunelege» - det ordet ein finn i lovgivinga - eller «kommuneoverlege», som i dag er kommunal stillingstittel. På same side er helsestasjon, skolehelseteneste og helseopplysning nemnt under overskrifta Samfunnsmedisinsk førstelinjetjeneste. Desse oppgåvene er i høg grad også del av allmennmedisinske arbeidsfelt, noko som bl.a. blei slått fast ved innføring av fastlegeordninga. Verre er det når ein på side 105 les at offentleg tannhelseteneste inngår i ansvaret til spesialisthelsetenesta og dei regionale helseføretaka. Denne oppgåva blei verande i fylkeskommunen i 2002, da spesialisthelsetenesta flytta ut.

I kapittel 15 om det fleirkulturelle samfunnet saknar eg ei nærare omtale av dei «papirlause», dei som ikkje har gyldig opphaldsløyve i landet. Dette er ei av dei svakaste og mest sårbare gruppene i samfunnet, ikkje minst når det gjeld tilgang til helse- og omsorgstenester.

Boka kan anbefalast både for studentar og for andre som ønskjer ei lettlest og oppdatert innføring i det sosialmedisinske fagfeltet. Vinklinga er i særleg grad tilpassa situasjonen i allmennmedisin.

Kristian Hagestad

Helsetilsynet i Vest-Agder

Kristiansand

Litteratur

1. Arnetz B. Sosialmedisin. Anmeldelse av: Mæland JG, Fugelli P, Høyer G, Westin

S, red. Sosialmedisin - i teori og praksis. Tidsskr Nor Lægeforen 2005; 125: 1700

\section{Godt, men ustrukturert om samliv}

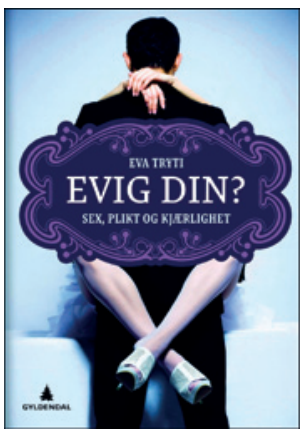

Eva Tryti

Sex, plikt og kjærlighet. $304 \mathrm{~s}$

Oslo: Gyldendal, 2011. Pris NOK 349

ISBN 978-82-05-40486-3

Eva Tryti er spesialist i klinisk voksenpsykologi og driver praksis for par og enkeltpersoner. I denne boken tar hun for seg det moderne parforholdets kår, muligheter og fallgruver, og prøver å svare på hva som skal til for å få parforhold til å vare. Målgruppen er, ifølge vaskeseddelen, «alle som er i et forhold eller ønsker å komme i et stabilt forhold».

Bakgrunnen for analysen er først og fremst hennes egen erfaring som par- og individualterapeut, men hun bruker i noen grad statistikk og henvisning til andre kilder. Hun fletter også inn noen kasuistikker fra praksisen sin.

Det er 15 kapitler, med temaer som kjærlighetsekteskapets historie, parforholdets byggesteiner, forholdet mellom trygghet og frihet, forskjellen på forelskelse og kjærlighet, og utroskap. Mesteparten er i fritekst, ispedd punktlister. Noen ganger er det en liste med råd på slutten av kapitlet, noen ganger ikke. Til slutt er det en fyldig litteraturliste.

Et gjennomgangstema er det Tryti kaller «parromantiske forestillinger», som hun mener gjennomsyrer mye av tenkningen vår rundt parforhold. De handler bl.a. om at kjærlighet er det viktigste grunnlaget for et varig parforhold, at det skal finnes én (eller noen få) som er «riktig» for bare meg, og at den dagen kjærligheten er borte, er forholdet dødt. Når kjærlighet i tillegg defineres som synonymt med forelskelse og begjær, er det duket for problemer, for de to er ganske ulike størrelser.

De parromantiske forestillingene sier videre at visse følelser spesielt de seksuelle - bare skal finnes $i$ parforholdet, og at noen følelser absolutt ikke skal finnes der. For eksempel er det å holde sammen av plikt eller praktiske årsaker ansett som mindreverdig. Dette illustreres ved tilfeller hvor noen bryter ut av et langvarig ekteskap pga. en forelskelse, med den begrunnelse at man må følge sine følelser, og at å bli i forholdet av plikt er en forbrytelse mot kjærligheten

Trytis poeng er at disse forestillingene gjør at vi tenker mindre rasjonelt når vi skal løse de hverdagslige problemene som alle par møter på. Og de forkludrer realitetene, bl.a. at vennskap og praktiske forhold betyr mer i det lange løp enn begjær og forelskelse.

Det er mye godt og interessant stoff her, men boken kunne med fordel vært strammet opp en del. Den er litt for omstendelig og pratsom, og temaene flyter for mye over i hverandre. Punktlistene og rådene virker ganske tilfeldig sammensatt, og de virker mer forstyrrende enn opplysende. Når det gjelder litteraturlisten, er den for akademisk til en bok hvor målgruppen er legfolk. Det hadde vært bedre med en kortere liste med forslag til videre lesning. Forsidebildet står ikke i stil med innholdet og kan ikke kalles annet enn spekulativt.

Det er likevel en bok som kan anbefales til, nettopp, alle som er $i$ et forhold eller ønsker å komme i et. Og andre interesserte.

\section{Pernille Nylehn}

Rehabilitering Vest

Haugesund 